\title{
Mieczyslaw Wolfke - a pioneer of holography
}

\author{
Krzysztof Petelczyc* \\ Faculty of Physics, Warsaw University of Technology, Koszykowa 75, 00-662 Warszawa, POLAND
}

Received July 28, 2021; accepted September 11, 2021; published December 31, 2021

\begin{abstract}
Receiving the Nobel Prize in 1971 for the invention and development of the holographic method, Dennis Gabor mentioned Mieczysław Wolfke as the person who proposed this method as early as 1920 (which he did not know, independently making the same discovery). This article describes the history of Wolfke's pioneering work and tries to recreate the thought process that led to it - starting with the task of supplementing and verifying the diffraction grating theory proposed by Ernst Abbe, which he carried out as part of his doctorate at the University of Wrocław and habilitation at the University of Zurich and the Swiss Federal Institute of Technology in Zurich.
\end{abstract}

According to the recollections of Witold Laniecki, a student and collaborator of Mieczysław Wolfke, his mentor valued the doctorate on the resolving power of diffraction gratings and the article from 1920 on imaging molecular grids as his own most significant achievements [1]. Such a statement is surprising, while the result of his work was also the method that allowed Willem Keesom to solidify helium for the first time [2] and their joint discovery of two types of liquid helium [3]. Even during Wolfke's lifetime, these achievements were widely echoed in the scientific world. This cannot be said about his achievements in optics [4], which were appreciated after half a century.

When Ernst Abbe, the optician who revolutionized the theory of imaging and the construction of optical systems, died in 1905, many of his achievements were not entirely written and published. The well-known scientist often presented his theories in the form of lectures and seminars. Their listener was, among others, Otto Lummer, a German physicist who played an essential role in the formation of quantum theory. In 1904 Lummer became a professor of physics at the University of Wrocław (at that time in Germany). In the face of Abbe's death, he made it a point of honor to write down the master's achievements in a complete and synthetic form. The culmination of this project was the book Die Lehre von der Bildentstehung im Microscope published in 1910 [5].

In the development of Abbe's theory, Lummer was supported by two younger collaborators - Mieczysław Wolfke and Fritz Reiche. The latter, just after a doctorate in Berlin from Max Planck, applied for a job at the University of Wrocław. On the other hand, Wolfke came to Wrocław for further studies (initially concerning the

${ }^{*}$ E-mail: krzysztof.petelczyc@pw.edu.pl influence of X-rays on radium) from the University of Paris. Both were characterized by the research abilities necessary to analyze and develop the mathematical equations and diffraction integrals used by Abbe [6, 7].

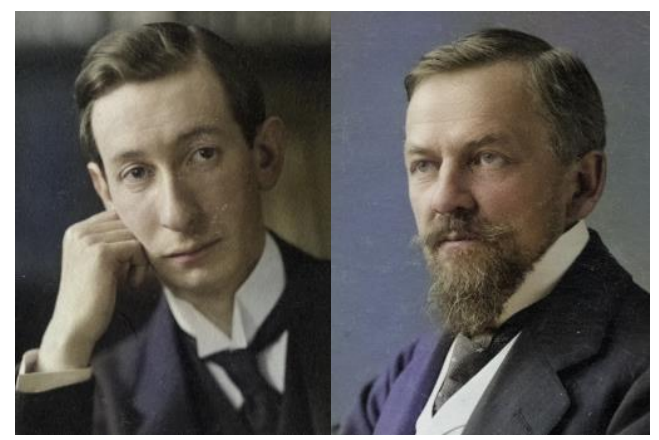

Fig. 1. Fritz Reiche and Otto Lummer, ca. 1910 (coloured).

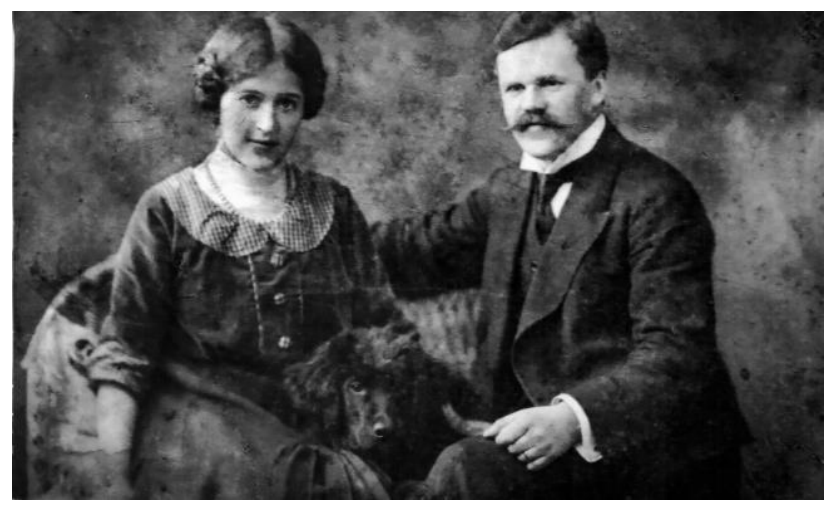

Fig. 2. Mieczysław Wolfke with his wife Agnes Erica, ca. 1912.

Reiche's work concerned the reconciliation of Abbe's theory with the modern theories of Kirchhoff and Maxwell. At the same time, Wolfke's doctorate verified compliance with the experiment of the theory of diffraction gratings imaging in a microscope with a diaphragm placed in the focal plane. The problem that we call today spatial filtration was meticulously derived theoretically and elaborated [8]. One conclusion was that no matter how obscured, the image is always symmetrical. Unfortunately, this conclusion did not agree with the results of the experiments, where for asymmetrical diaphragms, an asymmetrical image was also created. As Wolfke wrote: "the reason for this asymmetry of the image lies in the greater or lesser 
transparency of the mesh bars" (in the original source: przyczyna tej asymetrii obrazu leży $w$ większej lub mniejszej przezroczystości sztab siatki) [9]. After defending his doctorate, he developed this problem, supplementing and generalizing his theory into gratings with a non-binary transmittance profile and obtaining full compliance with the experiment [10-12]. The development of this topic was possible thanks to his employment in the scientific laboratories of the Carl-Zeiss Optical Plant in Jena - the same of which the "founding father" was Ernst Abbe. There, thanks to the support of the head of microscopy department, August Köhler, he obtained over sixty different diffraction gratings for examination - elements that were expensive and inaccessible at the time. It turned out that the silvering technique did not allow to obtain full opacity, and the less light the lattice bars let through, the better the diffraction pattern corresponded to the theory [13].

Working in the optics industry did not match Wolfke's ambitions. Therefore, he was looking for employment at university. Unfortunately, no position was created for him at the University of Wrocław, but in 1912 Wolfke got employed as an assistant to the "father of liquid crystals," prof. Otto Lehmann at the Karlsruhe Institute of Technology [13]. Hence the research area of the team focused on studying the crystalline structure of materials. This context was crucial in Wolfke's pioneering work in 1920, in which he treated atomic lattice as spatial diffraction grating. It is worth noting that these considerations were conducted while Paul Peter Ewald and Max von Laue published the world's first papers containing such an approach, and a year later, William Henry Bragg, with his son William Lawrence invented Xray diffraction [14]. They could inspire Wolfke in his research work. A year's work in Karlsruhe and experience in the physics of crystal lattices gave him the necessary knowledge and skills both in the field of optics and quantum approach, which was the subject of intensive work on redefining the concept of atoms and the structure of radiation.

Wolfke's dream was habilitation and the related veniam legendi (the right to lecture) at a leading European university. The achievement of this goal required summarizing and completing research on Abbe's theory. An unresolved issue was the generalization of the diffraction integrals to the incoherent light case where Abbe's equations did not correctly describe the experimental results. According to the terminology of the time, they concerned self-illuminating objects, i.e., extended light sources, and non-self-illuminating ones, i.e., slides illuminated by light transmitted through a pinhole or a slit. As Wolfke wrote, "the purpose of this work is to derive general equations for optical images of self-illuminating and non-illuminating objects using one and the same method, regardless of the object's position in relation to the set plane." (In the original source: celem pracy niniejszej jest wyprowadzenie równań ogólnych dla obrazów optycznych przedmiotów samoświecacych $i$ niesamoświecacych jedna $i$ ta sama metoda, $i$ to niezależnie od położenia przedmiotu $w$ stosunku do plaszczyzny nastawienia.) [15] Starting from the Huygens-Fresnel principle and applying the Lambert cosine law for the angles of incidence of light, he derived a theoretical model that correctly described the experimental results for both types of lighting [16] and generalized it to different positions of the input plane [17].

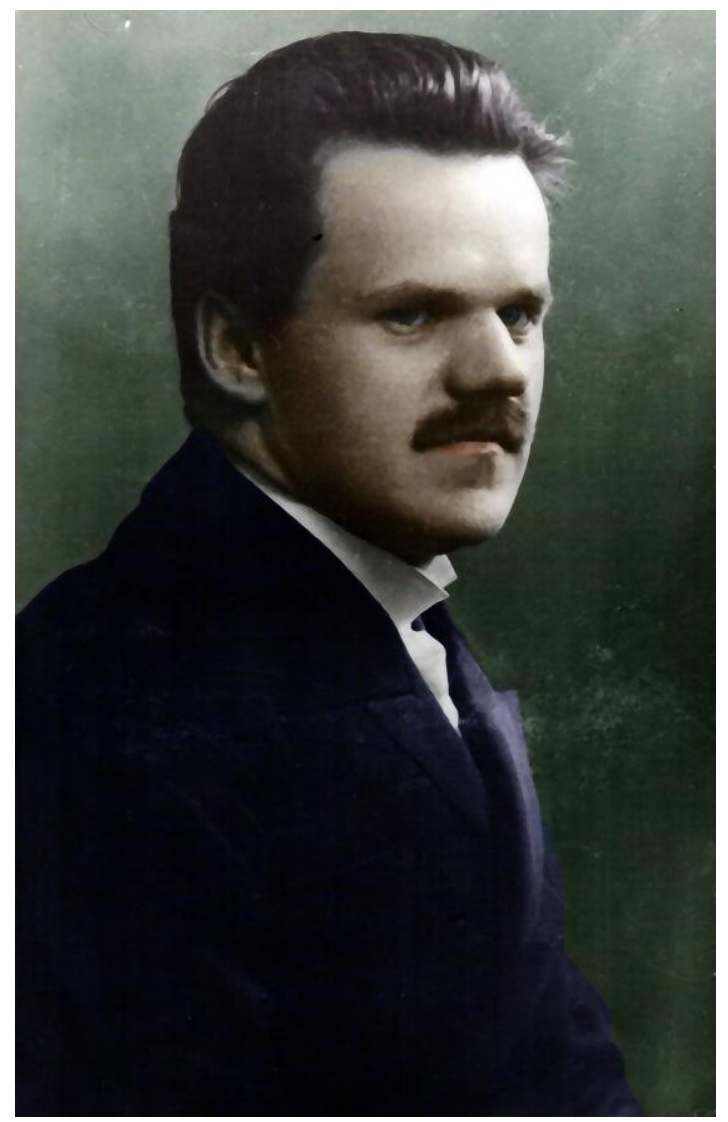

Fig. 3. Mieczysław Wolfke, 1915.

The developed theory became the basis for the habilitation in 1913 at the Swiss Federal Institute of Technology in Zurich, where Albert Einstein and Pierre Weiss reviewed Wolfke's achievements, and a year later at the University of Zurich with a favorable opinion of Max von Laue and Alfred Kleiner [13]. Wolfke settled in Switzerland, where he participated in meetings of scientists setting world trends in modern physics. He also published various models interpreting Einstein's light quanta and suggesting the concept of light molecules as possible excitation states of the cavity [18-21]. 
Meanwhile, the First World War was taking place in Europe, which changed the map of the continent. The most important result of the new geopolitical situation for Wolfke was the revival of his homeland - Poland, which disappeared from the maps of Europe, divided between Russia, Prussia, and Austria at the end of the 18th century. In 1920, Wolfke was offered the Chair of Theoretical Physics at the University of Warsaw. He resigned from work at both universities in Zurich, but the transfer to Poland eventually did not occur due to financial problems. Returning to the academic community in Zurich required repeating the habilitation procedure in 1921 (Edgar Meyer and Erwin Schrödinger were appointed reviewers). However, a year later, Wolfke was appointed professor at the Warsaw University of Technology with a promise to cover travel expenses and provide accommodation on the spot. In the review prepared for the competition for this position, the outstanding Polish physicist Stefan Pieńkowski analyzed Wolfke's scientific achievements, concluding that "the most serious achievements are the works (...) concerning light bending, made partly under the influence of the research of prof. Lummer; they constitute a certain unitary whole and give a clear solution to the question raised. The overall scientific activity of Dr. M. Wolfke shows a great scientific background, mastery of the newest directions of physics and easy mathematical approach to phenomena" (in the original source: najpoważniejszy dorobek stanowia prace (...) tyczace uginania światta, wykonane czesściowo pod wpływem badań prof. Lummera; stanowia one pewna jednolita całość $i$ daja wyraźne rozwiazanie postawionej kwestii. Całokształt działalności naukowej P. Dr. M. Wolfkego wykazuje wielkie wyrobienie naukowe, opanowanie najnowszych kierunków fizyki i łatwość matematycznego ujęcia zjawisk.) [22].

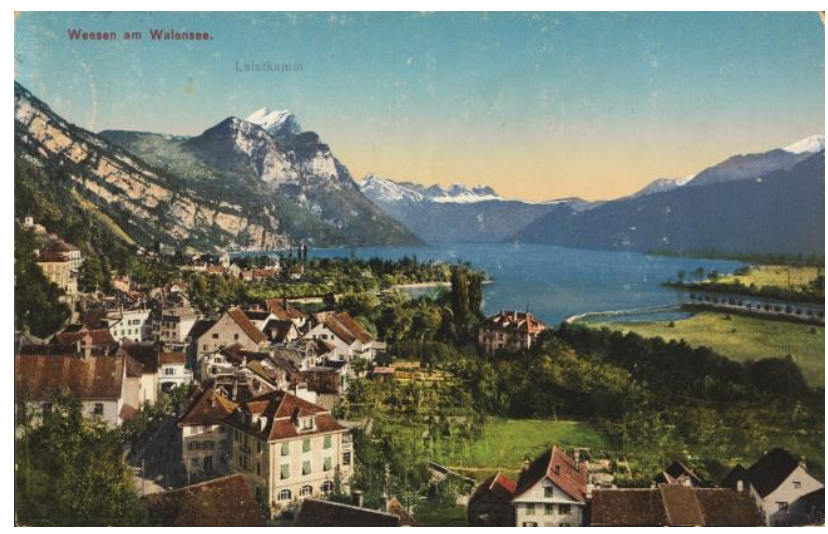

Fig. 4. Weesen, Switzerland, 1922.

Under these circumstances, most likely in the Hotel du Lac in Weesen, where Wolfke was preparing for his would-be move to Poland, a paper was created, which was first in the world to consider the concept of holography. The article published in Physikalische Zeitschrift is dated "April 1920" [23]. It was the culmination of optical imaging theory and expression of a concept that the author himself probably considered extremely brave. Indeed, before deciding to publish it, he was also looking for the possibility of experimentally verifying his considerations. Today we know that he had no chance of obtaining high-quality results due to the lack of strong, coherent light sources (the laser was not constructed until the year 1960). Therefore, Dennis Gabor was able to say in 1971, when receiving the Nobel Prize for the invention and development of the holographic method, that "Wolfke had proposed this method in 1920, but without realizing it experimentally" [24].

As the aim of the work Wolfke set himself was "a more detailed study of the possibilities of optical imaging of molecular structures" (in the original source: die Möglichkeit einer optischen Abbildung von molekularen Bebilden näher untersuchen) [23]. Then he stated that it is impossible to visualize the atomic structure classically because to achieve the necessary resolution, very short (X-ray) waves would have to be used, resulting in significant diffraction effects. Therefore, only the diffraction field image, called the primary image, is recordable. The reconstruction of the secondary image, geometrically similar to the imaged crystal lattice, faces the lack of optical elements working for such short wavelengths. Wolfke proposed to record the original image and then use visible light in the second part of the process after developing the film. He was aware that in order for this process to be successful, the subject had to meet specific additional requirements. He put it in the following theorem: "In monochromatic, parallel, orthogonal illumination, the diffraction image of a diffraction image of a symmetrical object without a phase structure will be identical to that object." (in the original source: Bei monochromatischer, paralleler, senkrechter Beleuchtung ist das Beugungsbild eines Beugungsbildes eines summetrischen Objektes ohne Phasenstruktur identisch mit dem Abblid dieses Objektes) [23] Then the author proves this theorem starting from the general equation of the optical imaging theory he developed [16] and confirms that he has verified its validity experimentally using various optical gratings and a parallel sodium light beam. However, he does not include the obtained images, stating that "to obtain a sharp image in these experiments, it was necessary to use very strong light beams and very small collimation holes" (in the original source: Bei diesen Versuchen muß, um scharfe Bilder zu erhalden, eine möglichst starke Lichtquelle mit sehr kleinem punktförmingen Kollimatorspalt benutzen werden) [23]. 


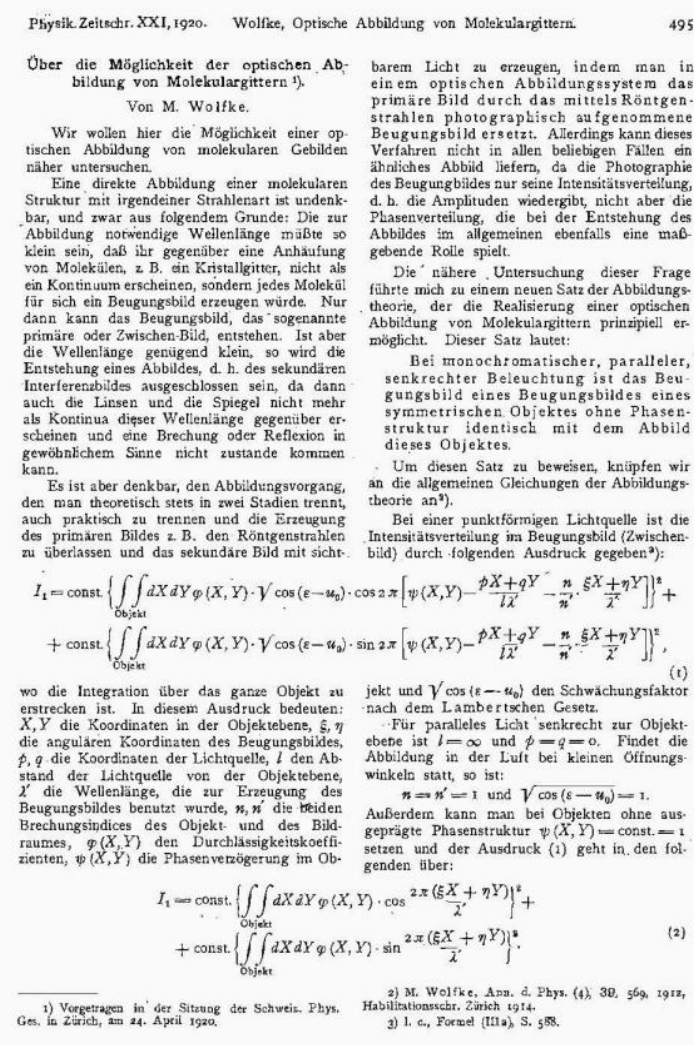

Fig. 5. First page of the original paper about the idea of holography from Physikalische Zeitschrift 21, 1920.

The conclusions of the work indicate the enlargement of the obtained image in a ratio of the reproducing and recording wavelengths, i.e., about 10,000 times, and the possibility of further optically magnifying the image up to 100 times. According to Wolfke, "this magnification is completely sufficient to visualize the molecular structure to obtain optical images of the crystal lattices." (in original source: Diese Vergrößerung würde vollständig genügen, um die Molekularstruktur sichtbar zu machen) The article concludes that the developed method allows for shifting the theoretical boundaries of optical imaging, which proves the awareness of the importance of this discovery for the history of physics. Unfortunately, at that time, optics was not technologically prepared for its implementation.

After arriving at the Warsaw University of Technology, Wolfke abandoned optical research to favor lowtemperature and electro-physical field. After the Second World War, he returned to Zurich to restore contacts, obtain technical means to rebuild laboratories, and update the state of knowledge from the works that did not reach Poland during the war. In 1947, he died suddenly without receiving recognition for his achievements in the field of optics.

\section{References}

[1] W. Łaniecki, Kwartalnik Historii Nauki i Techniki, 21, 545-553 (1976).

[2] W. Keesom, Nature 118, 81 (1926). doi: 10.1038/118081a0

[3] W. Keesom, M. Wolfke, Konink. Akad. Wetensch. Amsterdam, Proc, 31(190b), 90-94 (1928).

[4] W. Keesom, Helium (Elsevier, Amsterdam 1942)

[5] E. Abbe, Die Lehre von der Bildentstehung im Mikroskop (F. Vieweg, Braunschweig 1910).

[6] R. Torge, Postępy Fizyki, 53, 201-210 (2002).

[7] A.Kiejna, Kwartalnik Historii Nauki i Techniki, 48, 7 (2003).

[8] M. Wolfke, Ann Phys. 339, 277 (1911). 10.1002/andp.19113390206

[9] M. Wolfke, Prace matematyczno-fizyczne, 22, 135 (1911).

[10] M. Wolfke, Ann Phys. 342, 96 (1912). 10.1002/andp.19113420107

[11] M. Wolfke, Ann Phys. 342, 797 (1912). 10.1002/andp.19123420409

[12] M. Wolfke, Ann Phys. 343, 385 (1912). 10.1002/andp.19123430706

[13] K. Petelczyc, E. Kędzierska, Mieczystaw Wolfke. Gdyby mi dali choć pót miliona... (OWPW, Warszawa 2018).

[14] L.A. Aslanov, G.V. Fetisov, J.A.K. Howard, "Crystallographic Instrumentation", Oxford (1998).

[15] M. Wolfke, Wiadomości matematyczne 17, 1 (1913).

[16] M. Wolfke, Ann Phys. 344, 569 (1912). 10.1002/andp.19123441305

[17] M. Wolfke, Ann Phys. 345, 194 (1913). 10.1002/andp.19133450108

[18] M. Wolfke, Verhandlungen der DPG, 15, 1123 (1913).

[19] M. Wolfke, Verhandlungen der DPG, 15, 1215 (1913)

[20] M. Wolfke, Verhandlungen der DPG, 16, 4 (1914).

[21] M. Wolfke, Physikalische Zeitschrift, 22, 375 (1921).

[22] Akta osobowe - Wolfke Mieczysław, Archiwum Akt Nowych sygn. 2/14/0/6/6638, Warszawa

[23] M. Wolfke, Physikalische Zeitschrift, 21, 495 (1920).

[24] S. Lundqvist, Nobel Lectures, Physics 1971-1980 (World Scientific Publishing Co. Singapore 1992). 